\title{
Advances in Biosensors, Chemosensors and Assays for the Determination of Fusarium Mycotoxins
}

\author{
Xialu Lin and Xiong Guo * \\ Key Laboratory of Trace Elements and Endemic Diseases of National Health and Family Planning Commission, \\ School of Public Health, Health Science Center, Xi'an Jiaotong University, No.76 Yan Ta West Road, Xi'an, \\ Shanxi 710061, China; summer2047@yeah.net \\ * Correspondence: guox@mail.xjtu.edu.cn; Tel.: +86-29-8265-5091
}

Academic Editors: Maria C. DeRosa and Michelangelo Pascale Received: 8 April 2016; Accepted: 16 May 2016; Published: 24 May 2016

\begin{abstract}
The contaminations of Fusarium mycotoxins in grains and related products, and the exposure in human body are considerable concerns in food safety and human health worldwide. The common Fusarium mycotoxins include fumonisins, T-2 toxin, deoxynivalenol and zearalenone. For this reason, simple, fast and sensitive analytical techniques are particularly important for the screening and determination of Fusarium mycotoxins. In this review, we outlined the related advances in biosensors, chemosensors and assays based on the classical and novel recognition elements such as antibodies, aptamers and molecularly imprinted polymers. Application to food/feed commodities, limit and time of detection were also discussed.
\end{abstract}

Keywords: Fusarium; mycotoxins; biosensor; chemosensor; antibody; aptamer; molecularly imprinted polymer

\section{Introduction}

Fusarium mycotoxins are the general term of secondary metabolites produced by Fusarium species, the major families of which are fumonisins, trichothecenes, and zearalenone. Other emerging families of Fusarium mycotoxins include fusaproliferins, beauvercin, enniatins, butenolide, equisetin, moniliformin (MON) and fusarins [1]. They exist extensively in natural environment, especially in wheat, maize, rice, soybean and related byproducts. Fumonisins are mainly produced by Fusarium (F.) verticillioides and F. proliferatum. Approximately 15 different derivatives of fumonisins have been discovered, including fumonisin A1 (FA1), FA2, FB1, FB2, FB3, FB4, FC1, FC2, FC3, FC4 and FP1 [2]. The typical molecules of fumonisin compounds consist of a long hydroxylated hydrocarbon chain, with tricarballylic acid, methyl, and amino groups. Fumonisin B1 is the most toxic compound in this family, exhibiting hepato-, nephro-, immuno- and developmental toxicity in many animal species. It is also classified as Group 2B carcinogen (possibly carcinogenic to humans) by the International Agency for Research on Cancer [3]. Trichothecenes are mainly produced by Fusarium, Myrothecium, Trichoderma, Trichothecium, Cephalosporium, Verticimonosporium, and Stachybotrys. Over 200 mycotoxins are included in this family, all of which are sesquiterpene compounds [4]. According to the functional hydroxyl and acetoxy side groups' variations, trichothecenes are divided into type A to type D. HT-2 toxin and T-2 toxin are the representatives in type A, nivalenol (NIV) and deoxynivalenol (DON) in type B. T-2 toxin can be toxic through skin intact, air exposure, and other exposure pathways. It mainly affected the highly proliferative cells, tissues and organs, such as thymus gland, lymphoid tissue, bone marrow, astrointestinal tract, and skin [5]. DON is the deoxygenated derivatives of NIV; it is also called a vomitoxin, highly cytotoxic, affecting intestinal, hematopoietic, immune, endocrine, and nervous systems. Zearalenone (ZEN) is produced by several Fusarium and Gibberella sepcies, such as F. graminearum, F. culmorum, F. cerealis, F. equiseti, and F. verticillioides. ZEN and its derivatives, such as 
$\alpha$-zearalenol and $\beta$-zearalenol, are all potent estrogenic metabolites [6]. The reproductive system is the major toxicity target of this family toxin.

The contaminations of these Fusarium mycotoxins seriously influence the production of crops, the quality of agricultural products and animal feeds, and the safety of foods, and induce great economic losses and are great threats to human health. For this reason, the timely, rapid and accurate detection of the Fusarium mycotoxin contaminations in grain and its products, and the exposure level in human body are very important for risk monitoring and assessment. The classical analytical methods for Fusarium mycotoxins detections are the chromatographic techniques and chromatography-mass spectrometry linked techniques, which are based on the physical characteristics of toxins. These techniques need long and complicated sample pretreatment procedures, expensive instruments, skilled technicians and high determination cost, which are not suitable for the high-throughput detection of large samples. Based on the specific antigen-antibody reaction, traditional immunoassays, especially enzyme linked immuno-sorbent assay (ELISA) and lateral flow immunoassay (LFIA), are easy to perform and have been extensively used in the screening of Fusarium mycotoxins. However, there are some disadvantages, such as difficuly to automate the process, long testing time, or low sensitivity in different assays. There are some improvement, innovation and development on biorecognition assays. Meanwhile, novel developed optical, electrochemical, piezoelectric biosensors and chemosensors might be useful alternatives to solve these problems. In this review, we discussed these novel sensors and assays according to the recognition elements such as antibodies, aptamers and molecularly-imprinted polymers, and different detection signals.

\section{Novel Biosensors and Assays Based on Antibodies}

The antibody is the classical recognition element. Based on the specific immunological antibody-antigen reactions, many biosensors and assays have been developed, which are also called as immunosensors and immunoassays, respectively. Many immunosensors were developed from well-performed immunoassays. The transducer in immunosensors could directly or indirectly detect and measure the immunochemical reactions. According to the transducer types, immunosensors could be classified as optical, electrochemical, piezoelectric, and magnetic. Examples of the immunosensors and immunoassays for the detection of Fusarium mycotoxins are detailed in Tables 1-4.

\subsection{Optical Immunosensors and Immunoassays}

Optical immunosensor and immunoassays are important kinds of immunosensors and immunoassays that are widely used for detection. The optical signals in the immunosensor and immunoassays system include light absorbance, light polarization and rotation, fluorescence, luminescence and phosphoresence. The fluorescence polarization immunoassay is a well-known rapid and sensitive detection assay. The main optical immunosensors included surface plasmon resonance immunosensor, fiber-optic immunosensor, and fluorescent array immunosensor. The advances of these immunoassays and immunosensors for the determination of Fusarium mycotoxins are discussed as follow. 
Table 1. Recent biosensors and assays for fumonisins determination.

\begin{tabular}{|c|c|c|c|c|c|c|c|}
\hline Reference & Technique & Analyte & Element & Sample (Extraction) & LOD & Working Range & Detection Time \\
\hline [7], 1996 & Optical: fiber-optic & FB1 & antibody & buffer and corn ( $80 \%$ methanol) & $10 \mathrm{ng} / \mathrm{mL}$ & $10-1000 \mathrm{ng} / \mathrm{mL}$ & NA \\
\hline [8], 1998 & Optical: SPR & FB1 & antibody & NA & $50 \mathrm{ng} / \mathrm{mL}$ & NA & $<10 \min$ \\
\hline [9], 1999 & Optical: fiber-optic & FB1 & antibody & maize ( $75 \%$ methanol) & $0.4-3.2 \mu \mathrm{g} / \mathrm{g}$ & NA & NA \\
\hline [10], 2001 & Optical: FPIA & FB1, FB2, FB3 & antibody & maize (PBS) & $0.5 \mu \mathrm{g} / \mathrm{g}$ & $0.5-100 \mu \mathrm{g} / \mathrm{g}$ & $<30 \mathrm{~min}$ \\
\hline [11], 2010 & EC: amperometric & FB1, FB2 & antibody & corn (70\% methanol) & $5 \mathrm{ng} / \mathrm{mL}$ & $1-1000 \mathrm{ng} / \mathrm{mL}$ & NA \\
\hline$[12], 2012$ & Optical: CL & FB1, FB2 & antibody & maize flour (PBS) & $2.5 \mathrm{ng} / \mathrm{mL}$ & $2.5-500 \mathrm{ng} / \mathrm{mL}$ & $25 \mathrm{~min}$ \\
\hline [13], 2013 & Optical: FRET & FB1 & aptamer & maize (70\% methanol) & $0.01 \mathrm{ng} / \mathrm{mL}$ & $0.01-100 \mathrm{ng} / \mathrm{mL}$ & NA \\
\hline [14], 2013 & Optical & FB1 & aptamer & beer & $125 \mathrm{pg} / \mathrm{mL}$ & $125-1500 \mathrm{pg} / \mathrm{mL}$ & NA \\
\hline [15], 2014 & Optical: ECL & FB1 & aptamer & NA & $0.29 \mathrm{ng} / \mathrm{mL}$ & $\mathrm{NA}$ & NA \\
\hline [16], 2015 & Optical: FPIA & FB1, FB2 & antibody & maize ( $40 \%$ methanol) & $53.6-290.6 \mathrm{ng} / \mathrm{g}$ & $108.0-13166 \mathrm{ng} / \mathrm{g}$ & $30 \mathrm{~min}$ \\
\hline [17], 2015 & EC: amperometric & FB1, FB2, FB3 & antibody & $\begin{array}{l}\text { maize-based foodstuffs } \\
\text { (acetonitrile:PBS (50:50)), beer }\end{array}$ & $0.33 \mathrm{ng} / \mathrm{mL}$ & 0-1000 ng/mL & NA \\
\hline$[18], 2015$ & EC: impedimetric & FB1, FB2, FB3 & antibody & corn $(70 \%$ methanol $)$ & $0.46 \mathrm{pg} / \mathrm{L}$ & $7-49 \mathrm{pg} / \mathrm{mL}$ & NA \\
\hline [19], 2015 & microcantilever array & FB1 & aptamer & NA & $33 \mathrm{ng} / \mathrm{mL}$ & $0.1-40 \mu \mathrm{g} / \mathrm{mL}$ & NA \\
\hline [20], 2015 & EC: impedimetric & FB1 & aptamer & maize ( $20 \%$ methanol) & $2 \mathrm{pM}$ & $0.1 \mathrm{nM}-100 \mu \mathrm{M}$ & $40 \mathrm{~min}$ \\
\hline [21], 2015 & EC: amperometric & FB1 & antibody & cereal samples (70\% methanol) & $0.58 \mathrm{ng} / \mathrm{mL}$ & $0.6-54 \mathrm{ng} / \mathrm{mL}$ & NA \\
\hline [22], 2015 & EC: amperometric & FB1 & aptamer & wheat & $1 \mathrm{pg} / \mathrm{mL}$ & $1-106 \mathrm{pg} / \mathrm{mL}$ & NA \\
\hline [23], 2015 & EC: amperometric & FB1 & antibody & corn $(50 \%$ acetonitrile $)$ & $2 \mathrm{pg} / \mathrm{mL}$ & $0.01-1000 \mathrm{ng} / \mathrm{mL}$ & NA \\
\hline
\end{tabular}

Note: FB: Fumonisin B; LOD: limit of detection; NA: not available; SPR: Surface plasmon resonance; FPIA: Fluorescence polarization immunoassay; EC: electrochemical; CL:

chemiluminescence; FRET: fluorescence resonance energy transfer; ECL: electrochemiluminescence. 
Table 2. Recent biosensors, chemosensors and assays for the determination of trichothecenes and other mycotoxins.

\begin{tabular}{|c|c|c|c|c|c|c|c|}
\hline Reference & Technique & Analyte & $\begin{array}{l}\text { Recognition } \\
\text { Element }\end{array}$ & Sample (Extraction) & LOD & Working Range & Detection Time \\
\hline \multicolumn{8}{|c|}{ Deoxynivalenol (DON) and Nivalenol (NIV) } \\
\hline [24], 1999 & EC: amperometric & $\mathrm{DON}$ & redox reactions & rice samples ( $85 \%$ acetonitrile) & $9.1 \mu \mathrm{M} / 0.24 \mathrm{ppm}$ & $0.32-32 \mathrm{ppm}$ & NA \\
\hline [25], 2002 & Optical: FPIA & DON, 15-Ac-DON & antibody & wheat & NA & NA & NA \\
\hline [26], 2002 & Optical: FPIA & DON, 3-Ac-DON & antibody & wheat, maize (PBS) & $0.1 \mathrm{ng} / \mathrm{g}$ & NA & $5 \mathrm{~min}$ \\
\hline [27], 2002 & Optical: SPR & $\mathrm{DON}$ & antibody & $\begin{array}{l}\text { wheat ( } 10 \% \text { methanol, } 6 \% \\
\text { polyvinylpyrrolidone) }\end{array}$ & $2.5 \mathrm{ng} / \mathrm{mL}$ & $0.13-10.0 \mu \mathrm{g} / \mathrm{mL}$ & $15 \mathrm{~min}$ \\
\hline [28], 2003 & Optical: SPR & DON & antibody & wheat ( $80 \%$ acetonitrile) & NA & $2.5-30 \mathrm{ng} / \mathrm{mL}$ & NA \\
\hline [29], 2006 & $\begin{array}{l}\text { Optical: } \\
\text { fluorescent, array }\end{array}$ & $\mathrm{DON}$ & antibody & $\begin{array}{l}\text { cornmeal, cornflakes, wheat, barley, } \\
\text { oats and indoor air ( } 75 \% \text { methanol) }\end{array}$ & $\begin{array}{c}0.2 \mathrm{ng} / \mathrm{mL} \text { in buffer, } \\
50 \mathrm{ng} / \mathrm{g} \text { in oats, } 4 \\
\mathrm{ng} / \mathrm{L} \text { in air }\end{array}$ & NA & NA \\
\hline [30], 2006 & Optical: FPIA & DON & antibody & $\begin{array}{l}\text { durum wheat kernels, semolina, } \\
\text { and pasta }\end{array}$ & NA & & \\
\hline [31], 2010 & EC: amperometric & DON, 3-Ac-DON & Fab fragment & $\begin{array}{l}\text { wheat, breakfast cereal and baby-food } \\
(84 \% \text { acetonitril })\end{array}$ & $0.063 \mathrm{ng} / \mathrm{mL}$ & $100-4500 \mathrm{ng} / \mathrm{mL}$ & NA \\
\hline [32], 2010 & Optical: SPR & DON, 3-AcDON & antibody & $\begin{array}{c}\text { durum wheat, wheat products, and } \\
\text { maize-based baby foods } \\
(40 \% \text { methanol })\end{array}$ & $6-57 \mathrm{ng} / \mathrm{g}$ & $250-2000 \mathrm{ng} / \mathrm{g}$ & $6.5 \mathrm{~h} / 20$ samples \\
\hline [33], 2010 & Optical: SPR & NIV, DON & antibody & wheat (water) & $\begin{array}{l}\text { NIV:0.1 } \mu \mathrm{g} / \mathrm{g} ; \text { DON: } \\
0.05 \mu \mathrm{g} / \mathrm{g}\end{array}$ & NA & NA \\
\hline$[34,35], 2011,2012$ & Optical: BLI & DON & antibody & wheat flour (0.02 M phosphoric acid) & $0.10,0.09 \mu \mathrm{g} / \mathrm{g}$ & NA & NA \\
\hline [36], 2011 & Optical: OWLS & $\mathrm{DON}$ & antibody & wheat ( $60 \%$ acetonitrile) & NA & $0.01-50 \mathrm{ng} / \mathrm{mL}$ & NA \\
\hline [37], 2011 & EC: impedimetric & DON & antibody & food samples (water) & $0.3 \mathrm{pg} / \mathrm{mL}$ & $0.001-0.3 \mathrm{ng} / \mathrm{mL}$ & NA \\
\hline [38], 2011 & Optical: SPR & $\begin{array}{l}\text { DON, 3-ADON, } \\
\text { 15-ADON }\end{array}$ & MIP & standard solution & $>1 \mathrm{ng} / \mathrm{mL}$ & $0.1-100 \mathrm{ng} / \mathrm{mL}$ & NA \\
\hline [39], 2011 & EC: potentiometric & $\mathrm{DON}$ & antibody & PBS & $0.1 \mathrm{ppm}$ & NA & NA \\
\hline [40], 2012 & Optical: CL & $\mathrm{DON}$ & antibody & NA & $0.1 \mathrm{ng} / \mathrm{mL}$ & $0.1-10^{5} \mathrm{ng} / \mathrm{mL}$ & $20 \mathrm{~min}$ \\
\hline [41], 2014 & Optical: FPIA & DON & antibody & $\begin{array}{l}\text { wheat bran and whole-wheat } \\
\text { flour (PBS) }\end{array}$ & $120 \mathrm{ng} / \mathrm{g}$ & NA & $10-15 \mathrm{~min}$ \\
\hline [42], 2014 & EC: amperometric & DON & antibody & wheat (water) & $6.25 \mathrm{ng} / \mathrm{mL}$ & $6.25-250 \mathrm{ng} / \mathrm{mL}$ & NA \\
\hline [43], 2015 & Optical: ECL & DON & antibody & wheat flour & $1 \mathrm{pg} / \mathrm{mL}$ & $\begin{array}{l}0.005-100 \\
\mathrm{ng} / \mathrm{mL}\end{array}$ & NA \\
\hline [44], 2015 & EC: impedimetric & $\mathrm{DON}$ & antibody & wheat, roasted coffee and corn (water) & $0.3 \mathrm{ng} / \mathrm{mL}$ & $6-30 \mathrm{ng} / \mathrm{mL}$ & NA \\
\hline [45], 2015 & Optical: Q-body & DON & antibody & wheat (distilled water) & $6 \mathrm{ng} / \mathrm{mL}$ in wheat & $0.3-3000 \mathrm{ng} / \mathrm{mL}$ & NA \\
\hline
\end{tabular}


Table 2. Cont

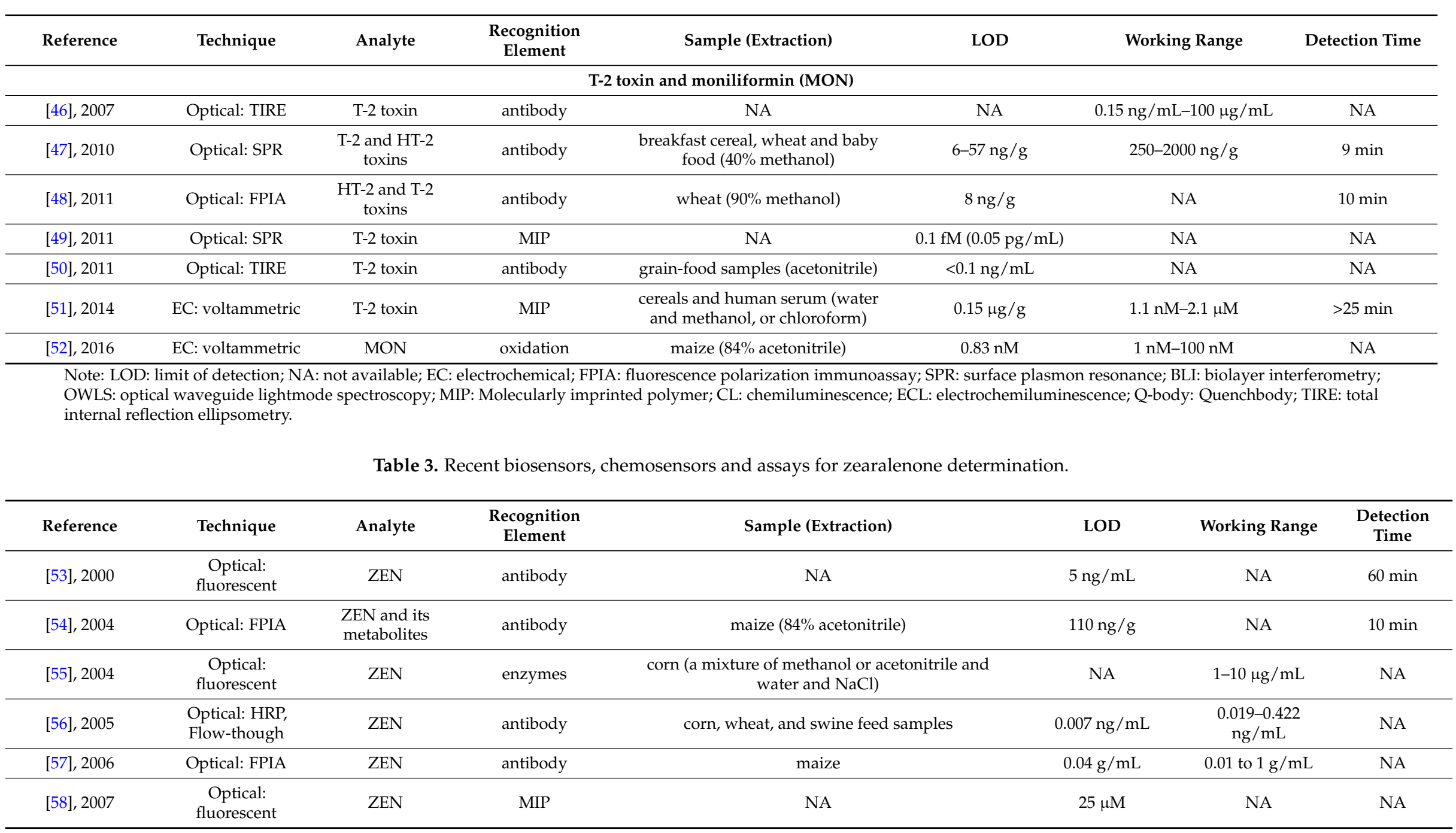


Table 3. Cont.

\begin{tabular}{|c|c|c|c|c|c|c|c|}
\hline Reference & Technique & Analyte & $\begin{array}{l}\text { Recognition } \\
\text { Element }\end{array}$ & Sample (Extraction) & LOD & Working Range & $\begin{array}{l}\text { Detection } \\
\text { Time }\end{array}$ \\
\hline [59], 2008 & $\begin{array}{l}\text { Optical: } \\
\text { fluorescent }\end{array}$ & ZEN & $\beta$-cyclodextrin & maize $\left(\mathrm{H}_{2} \mathrm{O}-\mathrm{CH}_{3} \mathrm{CN}\right.$ mixture $\left.(20: 80, v / v)\right)$ & $50 \mathrm{ng} / \mathrm{g}$ & NA & NA \\
\hline [60], 2009 & Optical: FPIA & ZEN & antibody & cereal products $(70 \%$ methanol and $4 \% \mathrm{NaCl})$ & $137 \mathrm{ng} / \mathrm{g}$ & $150-1000 \mathrm{ng} / \mathrm{g}$ & $<2 \mathrm{~min}$ \\
\hline [61], 2009 & EC: amperometric & ZEN & antibody & $\begin{array}{l}\text { maize, baby food, cereal (acetonitril:methanol (50:50) } \\
\text { or 75\% acetonitrile) }\end{array}$ & $0.011 \mathrm{ng} / \mathrm{mL}$ & NA & NA \\
\hline [62], 2009 & Optical: SPR & ZEN & MIP & corn $(70 \%$ methanol $)$ & $0.3 \mathrm{ng} / \mathrm{g}$ & $0.3-3000 \mathrm{ng} / \mathrm{mL}$ & NA \\
\hline [63], 2010 & $\begin{array}{l}\text { Optical: } \\
\text { bioluminescent }\end{array}$ & $\begin{array}{l}\text { ZEN and its } \\
\text { metabolites }\end{array}$ & yeast cells & milk ( $90 \%$ milk and $10 \%$ ethanol) & $2 \mathrm{nM}$ for $\mathrm{ZEN}$ & NA & $<3 \mathrm{~h}$ \\
\hline [64], 2010 & EC: amperometric & ZEN & antibody & corn silage ( $70 \%$ methanol) & $0.77 \mathrm{ppb}$ & $0-500 \mathrm{ppb}$ & NA \\
\hline [65], 2010 & EC: potentiometric & ZEN & antibody & baby food ( $75 \%$ acetonitrile) & $7 \mathrm{pg} / \mathrm{mL}$ & NA & NA \\
\hline [66], 2011 & Optical: FPIA & $\begin{array}{l}\text { ZEN and its } \\
\text { metabolites }\end{array}$ & antibody & corn $(60 \%-75 \%$ methanol) & $77 \mathrm{ng} / \mathrm{g}$ & $100-5000 \mathrm{ng} / \mathrm{g}$ & $3 \mathrm{~min}$ \\
\hline [50], 2011 & Optical: TIRE & ZEN & antibody & aqueous solutions & $0.1 \mathrm{ng} / \mathrm{mL}$ & NA & NA \\
\hline [67], 2011 & EC: amperometric & ZEN & antibody & feedstuffs ( $70 \%$ methanol) & $0.41 \mathrm{ng} / \mathrm{g}$ & $\mathrm{NA}$ & $30 \mathrm{~min}$ \\
\hline [68], 2012 & Optical: FPIA & ZEN & antibody & ground grain ( $60 \%$ methanol) & $3 \mathrm{ng} / \mathrm{mL}$ & $\mathrm{NA}$ & NA \\
\hline [69], 2013 & Optical: QD & ZEN & antibody & NA & $0.02-0.6 \mathrm{ng} / \mathrm{g}$ & NA & NA \\
\hline [70], 2013 & Optical & ZEN & aptamer & beer & $0.785 \mathrm{nM}$ & $3.14 \mathrm{nM}-31.4 \mu \mathrm{M}$ & NA \\
\hline [71], 2013 & EC: amperometric & ZEN & antibody & pig feed $(70 \%$ methanol) & $2.1 \mathrm{pg} / \mathrm{mL}$ & $0.005-25 \mathrm{ng} / \mathrm{mL}$ & NA \\
\hline [72], 2014 & EC: amperometric & ZEN & antibody & NA & $1.7 \mathrm{pg} / \mathrm{mL}$ & $0.005-15 \mathrm{ng} / \mathrm{mL}$ & NA \\
\hline [73], 2014 & $\begin{array}{l}\text { Optical: } \\
\text { fluorescent }\end{array}$ & ZEN & MIP & cereal crops (acetonitrile) & $0.002 \mu \mathrm{M}$ & $0.003-3.12 \mu \mathrm{M}$ & NA \\
\hline [74], 2015 & EC: amperometric & ZEN & oxidation & malt beverage samples & $0.58 \mathrm{ng} / \mathrm{mL}$ & $2.0-50 \mathrm{ng} / \mathrm{mL}$ & NA \\
\hline [75], 2015 & ELONA & ZEN & aptamer & corn $(70 \%$ methanol $)$ & $0.01 \mathrm{ng} / \mathrm{mL}$ & $0.03-2.5 \mathrm{ng} / \mathrm{mL}$ & NA \\
\hline [76], 2015 & EC: voltammetric & $\alpha-Z A L$ & antibody & bovine serum & $16 \mathrm{pg} / \mathrm{mL}$ & $0.05-50 \mathrm{ng} / \mathrm{mL}$ & $12 \mathrm{~min}$ \\
\hline [77], 2016 & PD-IPCR & ZEN & phage particles & corn, wheat and rice ( $60 \%$ methanol) & $6.5 \mathrm{pg} / \mathrm{mL}$ & $0.01-100 \mathrm{ng} / \mathrm{mL}$ & NA \\
\hline [78], 2016 & EC: voltammetric & ZEN & dsDNA & milk and wheat ( $85 \%$ acetonitrile for wheat) & $5 \mathrm{pg} / \mathrm{mL}$ & $0.008-20 \mathrm{ng} / \mathrm{mL}$ & NA \\
\hline
\end{tabular}

Note: ZEN: zearalenone; $\alpha$-ZAL: $\alpha$-zearalanone; LOD: limit of detection; NA: not available; FPIA: fluorescence polarization immunoassay; HRP: horseradish-peroxidase; MIP: Molecularly imprinted polymer; EC: electrochemical; SPR: surface plasmon resonance; TIRE: total internal reflection ellipsometry; QD: Quantum dot; ELONA: enzyme-linked oligonucleotide assay; PD-IPCR: phage display mediated immuno-PCR. 
Table 4. Recent biosensors, chemosensors and assays for the simultaneous determination of Fusarium and other mycotoxins.

\begin{tabular}{|c|c|c|c|c|c|c|}
\hline Reference & Technique & Analyte & Element & Sample (Extraction) & LOD (Working Range) & DT \\
\hline$[79], 2003$ & Optical: SPR & AFB1, ZEN, FB1, DON & antibody & NA ( $90 \%$ acetonitrile) & LOD: $0.01-50 \mathrm{ng} / \mathrm{g}$ & $25 \mathrm{~min}$ \\
\hline$[80], 2003$ & Optical: fluorescent, array & FB1, ricin, cholera toxin, etc. & antibody & NA & FB: $250 \mathrm{ng} / \mathrm{mL}$ & NA \\
\hline$[81], 2006$ & Optical: fluorescent, array & OTA, DON & antibody & $\begin{array}{l}\text { barley, cornmeal, wheat } \\
\text { and maize ( } 75 \% \text { methanol) }\end{array}$ & $\begin{array}{l}\text { LOD: (ng/g) DON: 1-180; } \\
\text { OTA: } 1-85 .\end{array}$ & NA \\
\hline$[82], 2006$ & Optical: fluorescent, array & OTA, DON, AFB1 and FB & antibody & NA & LOD: AFB1: $0.3 \mathrm{ng} / \mathrm{mL}$ & $15 \mathrm{~min}$ \\
\hline$[83], 2010$ & Magnetoresistive & AFB1, ZEN, HT-2 & antibody & NA & LOD: $50 \mathrm{pg} / \mathrm{mL}$ & \\
\hline [84], 2011 & Optical: SPR & DON, ZEN & antibody & $\begin{array}{c}\text { maize and wheat } \\
\text { (acetonitrile-water-formic } \\
\text { acid (84:16:1)) }\end{array}$ & $\begin{array}{l}\text { LOD: (ng/g) DON: 68-84; } \\
\text { ZEN: 40-64 }\end{array}$ & $14 \mathrm{~min}$ \\
\hline [85], 2012 & FRET & OTA, FB1 & aptamer & maize & $\begin{array}{c}\text { (ng/mL) OTA: } 0.02(0.05-100) \\
\text { FB1: } 0.1(0.1-500)\end{array}$ & NA \\
\hline$[86], 2014$ & Optical: QD & DON, ZEN, AFB1, T-2, FB1 & antibody & $\begin{array}{l}\text { wheat and maize samples } \\
\qquad(80 \% \text { methanol })\end{array}$ & $\begin{array}{l}\text { LOD: (ng/g) SAM FISA: DON: } \\
\text { 3.2, ZEN: 0.6, AFB1: 0.2, T-2: } \\
\text { 10, FB1: 0.4; DAM FISA: ZEN: } \\
\text { 1.8, AFB1: } 1 .\end{array}$ & NA \\
\hline$[87], 2014$ & Piezoelectric: QCM & AFB 1, OTA, FB1 & antibody & standard solution & Range: $0.5-10 \mathrm{ppb}$ & NA \\
\hline$[88], 2014$ & Optical: & OTA, FB1 & aptamer & $\begin{array}{l}\text { rice, corn, and wheat (60\% } \\
\text { methanol) }\end{array}$ & $\begin{array}{l}\text { (pg/mL) OTA: } 0.25(10-1000) \\
\text { FB1: } 0.16(1-1000)\end{array}$ & NA \\
\hline [89], 2015 & Optical: CL & FBs, AFB1 & antibody & maize flour (PBS) & $\begin{array}{l}\text { (ng/mL) FB1:0.6 (0.6-1500); } \\
\text { AFB1: } 0.15(0.15-50)\end{array}$ & $30 \mathrm{~min}$ \\
\hline [90], 2016 & Optical & ZENs, DONs, T-2 toxins, AFs, FBs, etc. & antibody & cereal food samples & $\begin{array}{l}\text { (ng/g) ZENs: } 0.04-0.17, \text { DONs: } \\
0.06-49 \text {, T-2 toxins: } 0.15-0.22, \\
\text { AFs: } 0.056-0.49, \text { FBs: } 0.53-1.05\end{array}$ & $20 \mathrm{~min}$ \\
\hline [91], 2016 & Optical: SPR & DON, ZEN, T-2, OTA, FB1, AFB1 & antibody & barley ( $80 \%$ methanol) & $\begin{array}{l}\text { (ng/g) DON: 26, ZEN: 6, T-2: } \\
\text { 0.6, OTA: 3, FB1: 2, AFB1: } 0.6\end{array}$ & NA \\
\hline
\end{tabular}

Note: AF: aflatoxin; AFB1: aflatoxin B1; ZEN: zearalenone; FB: fumonisin B; DON: deoxynivalenol; OTA: ochratoxin A; HT-2: HT-2 toxin; T-2: T-2 toxin; LOD: limit of detection; NA: not available; SPR: surface plasmon resonance; FRET: fluorescence resonance energy transfer; QD: Quantum dot; FLISA: fluorescent immunosorbent assay; SAM: single-analyte multiplex; DAM: double-analyte multiplex; QCM: quartz crystal microbalance; CL: chemiluminescence. 
Surface plasmon resonance (SPR) is a physical optics phenomenon at the interface between two different permittivity materials. The explanation and realization of SPR were extensively described by many reviews [92,93]. The SPR immunosensor was based on the detection of the mass concentration changes of analyte at the sensor surface. The first SPR immunosensor for FB1 detection was established by Mullett $e t$ al. in 1998 [8]. The specific antibodies were immobile on a gold film substrate and coupled to the glass slide. In the presence of different concentration FB1 in the sample cell, the resonance angle and reflected light intensity would be proportionally changed on the glass side and detected by the immunosensor [8]. Based on SPR, the rapid immunoassays for the DON [27,28,32,33], NIV [33] or T-2 toxin [47] detection were developed and improved subsequently, and applied in durum wheat, wheat products, maize-based baby foods, etc. SPR immunosensors for the simultaneous detection of two or more mycotoxins were also reported, such as "AFB1 (aflatoxin B1), ZEN, FB1 and DON" [79], "DON and ZEN" [84], and "DON, ZEN, T-2, OTA, FB1 and AFB1" [91] (see Table 4).

Fluorescence polarization immunoassay (FPIA) for Fusarium mycotoxins is based upon the change detection of fluorescence polarization signal before and after the competitive binding of fluorescently-labeled and unlabeled mycotoxin to the specific antibody. The fluorescently-labeled mycotoxin is called the FPIA tracer. It is in low molecular weight, and can rotate more rapidly, giving low fluorescence polarization signal. The signal is increased when the FPIA tracer binding to the antibody, which form a high molecular weight complex. After the extraction of samples, this assay is simple and easy to perform within a few minutes. These developed FPIAs were mostly applied to the detection in wheat or maize. The common fluoresceins and its derivatives for FPIA are fluorescein (FL), 4'-(aminomethyl) fluorescein (FL2), fluorescein isothiocyanate (FITC), 5- or 6- carboxy-fluorescein (CF), fluoresceinthiocarbamyl ethylenediame (EDF), 4'-(aminomethy) fluorescein hydrochloride (4'-AMF), fluoresceinthiocarbamyl hexamethylenediamine (HMDF) and [4,6-dichlorotriazine-2-yl]amino-fluorescein (DTAF). Maragos et al. reported the first application of FPIA in FB1 detection [10]. The FPIA tracer was labeled with 6-DTAF, and the assay got high cross-reactivity with FB2 (70\%) and FB3 (77\%) [10]. The FPIA with FB1-FITC and monoclonal antibody (mAb) 4B9 was found great cross-reactivity with FB2 (98.9\%) and screened out for the simultaneous detection of FB1 and FB2 [16]. Rapid FPIAs for DON were also established using tracer, DON-FL [25,30,41] or DON-FL2 [26], for HT-2 and T-2 toxins using HT2-FL ${ }_{1 a}$ [48], and for ZEN and its analogs using ZEN-FL [54,57], ZEN-HMDF [60], ZEN-4AMF [66], ZEN-EDF [68] or ZEN-AMF [68].

Besides FPIA, the fluoresceins were also applied to fluorescent biosensors. Carter $e t$ al. used the FITC labeled secondary antibody for ZEN detection [53]. Ngundi et al. labeled the anti-DON mAb with Cy5 bisfunctional dye for DON detection [29]. The fiber-optic immunosensor for FB1 measurement was developed and applied in maize samples $[7,9,94]$. In the study of Thompson et al., the FB1 labeled with fluorescein, FB1-FITC, was firstly saturated with the FB1 mAbs bound to a core optical fiber [7]. In the presence of FB1, there was a competition of the $\mathrm{mAb}$ binding sites, resulting in a decrease of fluoresce signals [7]. Several fluorescent array biosensors were built for simultaneous detection of "FB and other toxins" [80], "OTA and DON" [81], or "OTA, DON, AFB1 and FB" [82]. In such array, the fluorescent labeled specific antibodies or different biotinylated mycotoxins were often immobilized on the waveguide; during the detection, the conjugated mycotoxins were completed with different concentration of free mycotoxins in the sample to bind to the antibodies [80].

Quantum dots (QDs) are small semiconductor nanoparticles with stable photoluminescence and great fluorescence quantum yields. In the study of Beloglazova et al., the QD-loaded liposomes (phospholipids) were conjugate with ZEN as the fluorescent labels for the ZEN detection immunoassay [69]. Subsequently, the QDs were applied in the multiplex assay for simultaneous screening of DON, ZEN, AFB1, T-2 toxin and FB1 [86]. The sensitivity of the QD assay could be highly improved compared with the traditional fluorescent immunoassay or ELISA [69,86]. Quenchbody (Q-body) was a novel fluorescent technology. It contained a fluorophore in specific antibody domain, the fluorescence of which was quenched naturally. In sample analysis, the antigen was interacted with the Q-body and caused the fluorescence of Q-body to dose-dependently increase. Based on this, 
Yoshinari et al. developed an innovative immunosensor for DON determination using anti-DON Q-body [45].

There were other novel or modified optical immunosensors. Mirasoli et al. and Zangheri et al. applied the enzyme-catalyzed chemiluminescence (CL) in LFIAs for "FB1 + FB2" [12] or "AFB1 and FB1" [89] detection, the CL signals of which were measured by ultrasensitive cooled charge-coupled device sensor. Zhao et al. illustrated a novel chemiluminescent immunosensor for DON detection [40]. The DON antibodies were conjugated with the rotator $\varepsilon$-subunit of $\mathrm{F}_{0} \mathrm{~F}_{1}$-ATPase. During the detection, the concentration of DON in samples was indirectly indicated by the ATP synthetic activity of $\mathrm{F}_{0} \mathrm{~F}_{1}$-ATPase and measured by chemiluminesce through the luciferin-luciferase system [40]. Urraca et al. fabricated an automated flow-through fluorescent immunosensor for ZEN measurement, in which the ZEN in samples was competed with ZEN-HRP (horseradish-peroxidase) for the antibody binding site [56]. Nabok et al. combined the approaches of total internal reflection ellipsometry (TIRE) and immunoassay to develop the sensitive optical immunosensors for the detection of T-2 toxins [46,50] and ZEN [50]. Based on optical waveguide lightmode spectroscopy (OWLS) technique, Majer-Baranyi et al. established a direct and a competitive immunosensor for DON detection in spiked wheat samples [36]. Based on the biolayer interferometry (BLI) technology, Maragos et al. built an immunosensor for the DON detection in wheat flour [34]. In the presence of DON specific antibodies and the DON spike samples, there was a competition between the free and immobilized DON to bind to the antibodies [34]. When the materials bound to the tip of the fiber changed, the interference pattern of light reflected from the surface of this optical fiber was changed accordingly [34]. This BLI immunosensor was then modified by the amplification of the assay signal using the primary antibody labeled with colloidal gold [35]. Lv et al. fabricated an sensitive electrochemiluminescence (ECL) immunosensor with RuSi@Ru(bpy) ${ }_{3}{ }^{2+}$ for DON detection [43]. Nanoporous $\mathrm{Co}_{3} \mathrm{O}_{4}$ and $\mathrm{Au}$ were used to modify the electrode for electrode-driven luminescence process [43].

\subsection{Electrochemical Immunosensors and Assays}

The electrochemical immunosensor systems of mycotoxins were often composed of electrodes, binding layer with immobiling mycotoxins, primary antibody, secondary antibody labeled enzymes, reaction substrate and product, and transducer for measurements. The amperometric, potentiometric, conductimetric, voltammetric and impedimetric signals are often used in the electrochemical biosensors and assays to measure the mycotoxin affinity interactions to the analytical signal. Among them, amperometry was the most widely used one, and highly sensitive beyond the optical techniques.

Few electrochemical immunosensors for fumonisins detection were reported in the literatures. Kadir et al. developed the first electrochemical immunosensor for the detection of FB1 and FB2 in corn samples [11]. In this system, the ELISA for FBs was transferred to the gold screen-printed electrode surface, and the HRP enzyme label activity was detected by chronoamperometry using tetramethylbenzidine (TMB) and $\mathrm{H}_{2} \mathrm{O}_{2}$ substrate [11]. Jodra et al. explored a disposable electrochemical magnetoimmunosensor for FBs in the maize certified reference materials (CRMs) and beer samples [17]. In this sensor, the ELISA method of FBs were coupled with magnetic beads and transferred onto the surface of carbon screen-printed electrodes [17]. Masikini et al. illustrated an impedimetric fumonisin immunosensors based on the PdTe QDs-polymer-multi wall carbon nanotubes platform and applied it in the detection of corn CRMs [18]. In the FB1 electrochemical immunosensor of Yang et al., the nanocomposite film of single-walled carbon nanotubes (SWNTs) and chitosan (CS) were used to modify the electrical conductivity on glass carbon electrode (GCE) [23]. The electrochemical signal was from the reaction of alkaline phosphatase in secondary antibody and the substrate $\alpha$-naphthyl phosphate. Ezquerra et al. developed an eight-channel amperometric electrochemical array sensor for FB1 determination, and the antibodies were also fixed on the magnetic beads [21].

Several electrochemical immunosensors for DON detection were also reported. Romanazzo et al. developed an enzyme-linked-immunomagnetic-electrochemical assay for the detection of DON in wheat, breakfast cereal and baby food samples [31]. The immunomagnetic beads were coupled with 
eight magnetized screen-printed electrodes to form the electrochemical transducers. The recognition element of this assay, the Fab fragment against DON, showed high cross-reactivity with 3-Ac-DON [31]. In the electrochemical impedimetric immunosensor study of Wei et al., the GCE used for DON analysis was modified with a composite made from fullerene $\left(\mathrm{C}_{60}\right)$, ferrocene and the ionic liquid [37]. Kwon et al. fabricated the potentiometric immunosensor for DON analysis using the extended-gate metal oxide semiconductor field effect transistor [39]. Olcer et al. exhibited the detection of DON on a novel real-time amperometric electrochemical profiling platform with new electrode array, where $\mathrm{Au}$ quasi-reference electrode and shared reference/counter electrodes were comprised with the integrated microfluidics [42]. A label-free electrochemical impedimetric immunosensor for DON determination in wheat, roasted coffee and corm samples was fabricated by Sunday et al. using a gold nanoparticles-dotted 4-nitrophenylazo-functionalized graphene (AuNp/G/PhNO2) nanocatalyst [44].

Many studies have reported the electrochemical immunosensors for ZEN detection. Hervás et al. developed the ZEN electrochemical immunosensors using the antibody-coated magnetic beads for the detection of the maize CRMs and cereal-based baby food [61]. This immunosensor was modified using screen-printed electrodes [65]. The microfluidic chips [95] and electrokinetic magnetic beads [96] were also integrated into the electrochemical immunoassay for the ZEN determination to achieve in situ manipulation. Based on the GCE with multiwall carbon nanotubes, Panini et al. fabricated a ZEN immunosensor coupled with flow injection system for the detection in cereals [64]. In 2011 year study of Panini et al., the microfluidic immunosensor of ZEN was coupled with the gold electrode and the antibodies were immobilized on the 3-aminopropyl-modified magnetic microspheres [67]. Feng et al. fabricated a non-enzymatic amperometric biosensor for ZEN analysis in pig feed using nitrogen-doped graphene sheets to amplify signal at the sensor platform [71]. Nanoporous PtCo alloy was used to label the secondary antibody and improve the electrocatalytic activity to $\mathrm{H}_{2} \mathrm{O}_{2}$ [71]. Liu et al. developed an ultrasensitive label-free amperometric immunosensor for the ZEN determination [72]. In this sensor, the Au@AgPt nanorattles with high electron transfer rate were used for the immobilization of antibodies, and the mesoporous carbon was used for the loading of the nanorattles with large specific surface area [72]. Regiart et al. developed a novel sensor for $\alpha$-zearalanone ( $\alpha$-ZAL) determination by square-wave voltammertry on nanostructured functional platform [76]. The electrochemical sensors of FBs, trichothecenes and ZENs exhibited great sensitivity and simplicity, and should be encouraged to fabricate for simultaneous detection of mycotoxins.

\subsection{Piezoelectric, and Other Immunosensors}

The piezoelectric transducer is basically a mass balance, which could be used for the direct detection of the immunoreactions by mass alone, without any labels or secondary antibodies. The quartz crystal microbalance (QCM) was such an example, which consisted of a thin quartz disk with two gold electrodes. One of the electrodes was functionalized to sense the analyte. In the report of Spinella et al., a QCM-based piezoelectric immunosensor for detection of AFB1, OTA and FB1 was tested, in which the antibodies were immobilized on the DSP-coated gold quartz crystals [87]. In a QCM impedance study of Nabok et al., surprisingly large mass increase and film softening were measured as a result of specific binding between T-2 toxins and antibodies [46]. The suggested reason was the specific binding of large aggregates of hydrophobic molecules of T-2 toxins and the surrounding methanol solvent. However, Nabok et al. indicated that the biosensors based on the QCM for the quantification of T-2 toxins required further investigation [46]. Besides, there are a few other kinds of immunosensors. Mak et al. developed the magnetoresistive immunosensor for multiplex determination of AFB1, ZEN and HT-2 toxin [83]. The classic immunoassay was integrated into a magnetic nanotag detection platform [83]. Kong et al. developed a multi-immunochromatographic paper sensor for 20 types of mycotoxins detection, including ZENs, DONs, T-2 toxins, AFs, and FBs [90]. 


\section{Biosensors, Chemosensors and Assays Based on Novel Recognition Elements}

Based on the novel recognition elements, example of the biosensors and chemosensors for the detection of Fusarium mycotoxins are detailed in Tables 1-4.

\subsection{Aptamers Based Biosensors and Assays}

Aptamers are artificial short single stranded oligonucleotides with $20-80$ bases, either DNA or RNA, selected by a new combinatorial chemistry technology, the systematic evolution of ligands by exponential enrichment (SELEX). They can incorporate or integrate different targets, such as protein, enzyme, biotoxin, metallic ions, organic dyestuffs and pesticide, with high affinity and specificity through the spatial configuration complementary. The biosensor based on aptamer is also called as aptasensor.

Based on the FB1 aptamer screened by McKeague et al. [97], several recognition aptasensors and assays were developed. Wu et al. illustrated a novel fluorescence resonance energy transfer (FRET) system for FB1 analysis using quenchers, fluorophore and aptamers [13]. The sequences of molecular beacon (MB) was 5'-SH-( $\left.\mathrm{CH}_{2}\right)_{6}$-GCTCG CCAGCTTATTCAATT CGAGC- $\left(\mathrm{CH}_{2}\right)_{6}-\mathrm{H}_{2} \mathrm{~N}-3^{\prime}$, which is similar to part sequence of FB1 aptamers FB1 39. Complementary oligonucleotides to MB and FB1 aptamers was also synthesized, the sequence of which was 5'-AATTGAATAAGCTGG-3'. They attached the quenchers, gold nanoparticles (AuNPs) to the $5^{\prime}$ end of $\mathrm{MB}$, and the fluorophore donors, NaYF4: Yb, Ho upconversion fluorescent nanoparticles (UCNPs) to the $3^{\prime}$ end of the MB. There is a hairpin-like stem-loop structure in the MB, where the fluorophore and quenchers were close, resulting in fluorescence quenching. In the first stage of analysis, the FB1 aptamers conjugated by the carboxylation-functionalized magnetic nanoparticles were hybridized with the complementary oligonucleotides. Then in presence of the samples with FB1, there were competitive bindings between FB1 and complementary oligonucleotides to aptamers. Due to the high affinity binding of FB1 and its aptamers, the complementary oligonucleotides were released, which could bound the loop of MB and form double stranded DNA, leading the fluorescence restoration. Finally, the concentration of FB1 was indirectly quantified by the fluorescence [13]. In sodium citrate buffer solution, the AuNPs were homogeneous and stable, showing red color. As the increase aggregation extent of AuNPs, red, purple, or blue color is exhibited in the solution. Wang et al. developed an aptasensor of FB1 with AuNPs [14]. One AuNPs solution was conjugated with a DNA1 sequence, 5'-SH-AATTGAATAAGCTGGTA-3', which was complementary to part sequence of FB1 aptamers FB1 39. Another AuNPs solution was conjugated with DNA2 sequences, 5'-SH-TACCAGCTTATTCAATT-3', which was complementary to DNA1. The DNA1-AuNPs solution was incubated with FB1 aptamers FB1 39 to make the sequence hybridization. In presence of FB1 solution, some FB1 aptamers were deviated from DNA1 sequence and bound to FB1 with high affinity. The liberative DNA1-AuNPs were then hybridized with DNA2-AuNPs, which made AuNPs close and changed the solution color. This assay indirectly detected the concentration of FB1 through its correlation with the color variation of AuNPs solution, the color of which could be quantified by the ultraviolet-visible spectrophotometry. Zhao et al. fabricated an ECL aptasensor for FB1 detection [15]. The nanoprobes of Au NPs and ionic iridium complex (novel ECL labels) were covalent with FB1 aptamers. The Au electrode was modified with DNA partial complementary (PC-DNA) to FB1 aptamer. With the concentration of FB1 increased in aptasensor, the ECL intensity would inverse proportionally decrease [15]. Chen et al. built a simple and sensitive FB1 aptasensor based on the microcantilever array sensors [19]. The reference microantilevers were only functionalized 6-mercapto-1-hexanol self-assembled monolayers, while the sensing microcantilevers were modified with SAMs of the FB1 aptamer FB1 39. In presence of FB1 sample solution, the sensing cantilevers could specifically combine the FB1 and lead to the deflection. The FB1 concentration could be indirectly quantified by this difference on the microcantilever biosensor. An impedimetric aptamer-based biosensor was developed to detect FB1 in maize samples [20]. The working electrode apF10/AuNPs/GCE was fabricated with GCE, modified by AuNPs on the surface, and conjugated with the FB1 aptamer F10. When the FB1 bound to the apF10/AuNPs/GCE electrode, there was higher 
inhibition of the electron transfer between the electrolyte buffer and this electrode, and larger resistance. The concentration of FB1 was indirectly related the change of electron transfer resistance $\left(R_{\mathrm{et}}\right)$, and measured by the electrochemical impedance spectroscopy [20]. Shi et al. designed an electrochemical aptasensor for FB1 detection [22]. The GCE was modified by Au NPs, covalent with capture DNA and hybridized with FB1 aptamers. The graphene/thionine nanocomposites (GS-TH) were loaded to increase the electrochemical signal. In the presence of increasing FB1 concentration, the electrochemical signal would inversely decrease following the release of aptamers and GS-TH on GCE [22].

In 2013, Chen et al. isolated and identified a ZEN aptamer [70]. In this assay, the ZEN aptamer was labeled with biotin and coupled with streptavidin-coated magnetic beads. The ZEN in sample solutions was pre-concentrated by this ZEN aptamer, then separated and enriched by magnetic force and finally detected by fluorescence spectrophotometer [70]. This ZEN aptamer was supposed to be applied to biosensors. A high specificity and affinity aptamer of the monoclonal antibody against ZEN (mAb-ZEN) was identified by Wang et al. [75]. Moreover, an enzyme-linked oligonucleotide assay of ZEN was developed based on it. To detect the ZEN content, the mAb-ZEN was coated on microtiter plate. Then, ZEN solutions, the biotinylated mAb-ZEN aptamers, and HRP-conjugated streptavidin were successively incubated and washed. Finally, the TMB buffer was used for coloration, and the absorbance was measured by a microplate reader [75]. The LOD of DNA aptamer based sensors for FBs or ZENs determination could reach to "pg/mL" levels. However, there is a lack of the application of DNA aptamer on trichothecenes mycotoxin analysis.

Two simultaneous determination aptasensors of OTA and FB1 was developed. In the study of Wu et al. [85], two fluorophore donors, UCNPs of $\mathrm{BaY}_{0.78} \mathrm{~F}_{5}: \mathrm{Yb}_{0.2}, \mathrm{Er}_{0.02}$ and $\mathrm{BaY}_{0.78} \mathrm{~F}_{5}: \mathrm{Yb}_{0.7}$ were immobilized with OTA and FB1 aptamers, respectively [85]. Because of the strong $\pi-\pi$ stacking effect, there was a spontaneous combination between the quenchers graphene oxide (GO) and the aptamers-UCNPs, resulting in the fluorescence quenching. When OTA and FB1 were involved, the nucleobases of aptamers were coupled with them instead of GO [85]. Its application on maize samples was conducted, and the measure results showed high correlation with the commercially available ELISA. In the study of Sun et al. [88], the surface of silica photonic crystal microphere was immobilized with the OTA or FB1 aptamers. Subsequently, the FITC labeled complementary DNA of related aptamers were used for hybridization. In the absence of OTA and FB1, the fluorescent intensities were high; in the presence of OTA and FB1, the related aptamers preferred to bind the target mycotoxins with high affinity and disassociated the complementary DNA, resulting in the decrease of fluorescence [88]. The measure results of its application on contaminated wheat, maize and rice samples were highly correlated with the classic ELISAs of OTA $\left(R^{2}=0.913\right)$ and FB1 $\left(R^{2}=0.993\right)$ [88].

\subsection{Molecularly Imprinted Polymer Based Chemosensors}

Molecularly imprinted polymers (MIPs) are artificial polymers with high affinity to specific molecules. Initially, the functional monomers were bound to the template molecules. Then, they were polymerized by crosslinkers. Finally, the template molecules were removed by physical or chemical methods, and left three-dimensional complementary cavities in the polymer matrix. Based on the technique of MIP and transducer, optical, electrical or quality chemosensor could be established for mycotoxin analysis.

Based on the MIP, Navarro-Villoslada et al. developed a chemosensor based on fluorescence displacement assay for ZEN analysis [58]. In the photo-polymerization of MIP, the cyclododecyl 2,4-dihydroxybenzoate (CDHB) was the synthetic mimics used as the templated molecule for ZEN; the 1-Allylpiperazine was the functional monomer. As the control, the non-imprint polymer was also synthesized without the template molecules. The fluorescent probe, 2,4- dihydroxybenzoic acid 2-[(pyrene-l-carbonyl)amino] ethyl ester (PARA) was tailor-made analogous to ZEN, and found high sensitivity to MIP and high sample throughput. This MIP/PARA-based fluorescence displacement sensor showed high sensitivity in ZEN solutions and high cross-reactivity with $\beta$-zearalenol [58]. In 2009 year, Choi et al. synthesized a molecularly imprinted polypyrrole (MIPPy) film on the Au SPR 
chip for ZEN detection [62]. Using a three-electrode electrochemical system, the functional monomer pyrroles were bound to template molecules ZEN, and electropolymerized on the Au SPR chip under the electrolytes of tetraethylammonium tetrafluoroborate. After the synthesis of this film, the ZEN and electrolytes in the polymeric matrix were removed by successive washing procedure in acetonitrile, methanol and chloroform. The films without the template molecules ZEN were also synthesized, called non-MIPPy. The SPR reflected intensities were measured on the MIPPy or non-MIPPy in the presence of ZEN. At the minimum SPR intensity, different concentration ZEN solutions were tested to determine the resonance angle shifts [62]. Using similar synthesis method, the MIPPy-SPR sensor for DON detection was also developed [38]. Gupta et al. developed a supersensitive chemical sensor for T-2 toxin analysis using MIP and SPR [49]. In the study of Gao et al., the voltammetric electrochemical sensor for T-2 toxin determination was fabricated based on $\mathrm{Fe}^{3+}$-ion molecularly imprinted film [51]. This MIP sensor was successfully applied in cereals and human serum samples [51]. Based on the ionic liquid-stabilized CdSe/ZnS QDs, Fang et al. established a molecularly imprinted optosensing material (MIOM) for ZEN detection in the fluorescence sensors [73]. During the polymerization of MIOM, CDHB was used as the template molecules, and the modified CdSe/ZnS QDs were bound to the polymers as the fluorescent labels. The similar material without CDHB was also synthesized, called non-imprinted optosensing material. With the addition and binding of different concentration ZEN, the fluorescence intensity of MIOM would be accordingly quenched, and detected by spectrofluorometry. This MIOM of ZEN showed high recoveries for corn, rice and wheat flour samples [73].

\subsection{Other Biosensors, Chemosensors and Assays}

Beyond aptamers and molecularly imprinted polymers, there were a few other elements used for the recognition of Fusarium mycotoxins and applied in the sensors and assays, such as oxidation response on electrodes, $\beta$-cyclodextrin, yeast cells, and phages. Hsueh et al. illustrated an indirect electrochemical sensor for DON screening based on DON hydrolysis products in basic solutions, and employed it in rice samples [24]. Afzali et al. developed an electrochemical sensor for ZEN determination in beverage samples [74]. The oxidation response changes of ZEN were observed at multi-walled carbon nanotube modified carbon paste electrodes [74]. Toro $e t$ al. developed a novel electrochemical sensor for MON quantification in maize samples [52]. The electrochemical oxidation of MON was adsorbed at cysteamine self-assembled monolayers on gold electrodes and recorded by cyclic voltammograms [52]. Sadrabadi et al. designed a DNA based electrochemical biosensor for ZEN evaluation in wheat and milk samples [78]. The interaction between ZEN and double-stranded DNA was shown as the oxidation signal of adenine, and detected by differential pulse voltammetry at a pencil graphite electrode [78]. Dall'Asta et al. investigated the complexation mechanism between the ZEN and $\beta$-cyclodextrin, and reported the chemosensor for ZEN detection in maize samples [59]. Välimaa et al. developed a bioluminescent whole-cell biosensor for the detection of ZEN and its metabolites in milk products [63]. The modified firefly (Photinus pyralis) luciferase reporter gene $(l u c)$ was inserted into the engineered yeast cells under the control of a hormone-responsive element (HRE). The present estrogenic ligands in the cell were bound to the constitutively expressed hormone receptors and in turn, to the HRE, which could induce the $l u c$ gene expression. In the presence of D-luciferin substrate, different intensity luminescence was produced [63]. Andreu et al. reported a fluorometric-enzymatic assay for ZEN detection in corn samples [55]. The ZEN could react with $\beta$-NADH in the presence of the enzyme $3 \alpha$-hydroxysteroid dehydrogenase, and the fluorescence intensity changes of $\beta$-NADH were measured [55]. The phage display mediated immunopolymerase chain reaction (PD-IPCR) is a novel and sensitive technology combined with immunoassay and PCR. A PD-IPCR for ZEN determination was developed and applied in cereals [77]. The variable domain of heavy-chain (VHH) anti-ZEN antibodies was used to produce anti-idiotypic VHH phages, which showed high affinity to anti-ZEN mAb. The phage particles of anti-idiotypic VHH phage clone Z1 was used to compete with the ZEN for antibody interaction and provided DNA templates for PCR. The fluorescence signals of PD-IPCR could sensitively reflect the concentration of ZEN [77]. 


\section{Conclusions and Prospects}

In the past two decades, there has been significant technological progress in optical, electrochemical, piezoelectric and other kinds of biosensors, chemosensors and assays for the determination of Fusarium mycotoxins, such as fumonisins, HT-2 toxin, T-2 toxin, nivalenol, deoxynivalenol and zearalenone. The sensitivity and efficiency were greatly improved by these novel sensors and assays. Besides classic antibodies, many novel recognition elements, such as aptamers and molecularly imprinted polymers, were usefully developed and applied in some mycotoxin detections. However, the novel exploitations to more mycotoxin families are still needed. The contamination level of mycotoxins in food and feed, and the exposure level in human body are both important issues for risk monitoring and assessment. More complex matrices, such as human plasma and urine, are needed to investigate. Meanwhile, the detection methods for multiple Fusarium mycotoxins are still very limited, and need more efforts to study.

Acknowledgments: This study was supported by Grants from the National Natural Science Foundation of China (81472924) and the Fundamental Research Funds for the Central Universities in Xi'an Jiaotong University.

Conflicts of Interest: The authors declare no conflict of interest.

\section{Abbreviations}

The following abbreviations are used in this manuscript:

$\begin{array}{ll}\text { AFB } & \text { aflatoxin B } \\ \text { AuNP } & \text { gold nanoparticle } \\ 4^{\prime} \text {-AMF } & \text { 4'-(aminomethy) fluorescein hydrochloride }^{\prime} \text { biolayer interferometry } \\ \text { CF } & \text { 5- or 6- carboxy-fluorescein } \\ \text { CL } & \text { chemiluminescence } \\ \text { CRM } & \text { certified reference material } \\ \text { CS } & \text { chitosan } \\ \text { CDHB } & \text { cyclododecyl 2,4-dihydroxybenzoate } \\ \text { DAM } & \text { double-analyte multiplex } \\ \text { DON } & \text { deoxynivalenol } \\ \text { DTAF } & \text { [4,6-dichlorotriazine-2-yl]amino-fluorescein } \\ \text { EC } & \text { electrochemical } \\ \text { ECL } & \text { electrochemiluminescence } \\ \text { EDF } & \text { fluoresceinthiocarbamyl ethylenediame } \\ \text { ELISA } & \text { enzyme linked immuno-sorbent assay } \\ \text { ELONA } & \text { enzyme-linked oligonucleotide assay } \\ \text { F. } & \text { Fusarium } \\ \text { FA } & \text { fumonisin A } \\ \text { FB } & \text { fumonisin B } \\ \text { FC } & \text { fumonisin C } \\ \text { FITC } & \text { fluorescein Isothiocyanate } \\ \text { FL } & \text { fluorescein } \\ \text { FL2 } & \text { 4'-(aminomethyl) fluorescein } \\ \text { FLISA } & \text { fluorescent immunosorbent assay } \\ \text { FRET } & \text { fluorescence resonance energy transfer } \\ \text { FP } & \text { fumonisin P } \\ \text { FPIA } & \text { fluorescence polarization immunoassay } \\ \text { GCE } & \text { glass carbon electrode } \\ \text { GO } & \text { graphene oxide } \\ \text { HMDF } & \text { fluoresceinthiocarbamyl hexamethylenediamine } \\ \text { HRE } & \text { hormone-responsive element } \\ \text { HRP } & \text { horseradish-peroxidase } \\ \text { LFIA } & \text { lateral flow immunoassay } \\ \text { LOD } & \text { limit of detection } \\ \text { mAb } & \text { molecular beacon } \\ \text { MB } & \\ \text { MIP } & \end{array}$




\begin{tabular}{ll} 
MIOM & molecularly imprinted optosensing material \\
MIPPy & molecularly imprinted polypyrrole \\
MON & moniliformin \\
NA & not available \\
NIV & nivalenol \\
OTA & ochratoxin A \\
OWLS & optical waveguide lightmode spectroscopy \\
PARA & 2,4- dihydroxybenzoic acid \\
PC-DNA & 2-[(pyrene-L-carbonyl)amino] ethyl ester \\
PD-IPCR & DNA partial complementary \\
QCM & phage display mediated immuno-PCR \\
QD & quartz crystal microbalance \\
Q-body & quantum dot \\
SAM & suenchbody \\
SELEX & systematic evolution of ligands by exponential \\
enrichment \\
SPR & surface plasmon resonance \\
SWNTs & single-walled carbon nanotubes \\
TIRE & total internal reflection ellipsometry \\
T-2 & T-2 toxin \\
TMB & tetramethylbenzidine \\
UCNP & upconversion fluorescent nanoparticles \\
VHH & variable domain of heavy-chain \\
$\alpha-Z A L$ & $\alpha$-zearalanone \\
ZEN & zearalenone \\
& \\
\hline
\end{tabular}

\section{References}

1. Desjardins, A.E.; Proctor, R.H. Molecular biology of Fusarium mycotoxins. Int. J. Food Microbiol. 2007, 119, 47-50. [CrossRef] [PubMed]

2. Stockmann-Juvala, H.; Savolainen, K. A review of the toxic effects and mechanisms of action of fumonisin B1. Hum. Exp. Toxicol. 2008, 27, 799-809. [CrossRef] [PubMed]

3. International Agency for Research on Cancer (IARC). Summaries \& Evaluations, Fumonisin B1. IARC Monogr. Eval. Carcinog. Risks Hum. 2002, 82, 301.

4. Escrivá, L.; Font, G.; Manyes, L. In vivo toxicity studies of Fusarium mycotoxins in the last decade: A review. Food Chem. Toxicol. 2015, 78, 185-206. [CrossRef] [PubMed]

5. Li, Y.; Wang, Z.; Beier, R.C.; Shen, J.; Smet, D.D.; de Saeger, S.; Zhang, S. T-2 toxin, a trichothecene mycotoxin: Review of toxicity, metabolism, and analytical methods. J. Agric. Food Chem. 2011, 59, 3441-3453. [CrossRef] [PubMed]

6. Zinedine, A.; Soriano, J.M.; Moltó, J.C.; Mañes, J. Review on the toxicity, occurrence, metabolism, detoxification, regulations and intake of zearalenone: An oestrogenic mycotoxin. Food Chem. Toxicol. 2007, 45, 1-18. [CrossRef] [PubMed]

7. Thompson, V.S.; Maragos, C.M. Fiber-optic immunosensor for the detection of fumonisin B1. J. Agric. Food Chem. 1996, 44, 1041-1046. [CrossRef]

8. Mullett, W.; Lai, E.P.; Yeung, J.M. Immunoassay of fumonisins by a surface plasmon resonance biosensor. Anal. Biochem. 1998, 258, 161-167. [CrossRef] [PubMed]

9. Maragos, C.M.; Thompson, V.S. Fiber-optic immunosensor for mycotoxins. Nat. Toxins 1999, 7, 371-376. [CrossRef]

10. Maragos, C.M.; Jolley, M.E.; Plattner, R.D.; Nasir, M.S. Fluorescence polarization as a means for determination of fumonisins in Maize. J. Agric. Food Chem. 2001, 49, 596-602. [CrossRef] [PubMed] 
11. Kadir, M.K.A.; Tothill, I.E. Development of an electrochemical immunosensor for fumonisins detection in foods. Toxins 2010, 2, 382-398. [CrossRef] [PubMed]

12. Mirasoli, M.; Buragina, A.; Dolci, L.S.; Simoni, P.; Anfossi, L.; Giraudi, G.; Roda, A. Chemiluminescence-based biosensor for fumonisins quantitative detection in maize samples. Biosens. Bioelectron. 2012, 32, $283-287$. [CrossRef] [PubMed]

13. Wu, S.; Duan, N.; Li, X.; Tan, G.; Ma, X.; Xia, Y.; Wang, Z.; Wang, H. Homogenous detection of fumonisin $\mathrm{B} 1$ with a molecular beacon based on fluorescence resonance energy transfer between NaYF4: Yb, Ho upconversion nanoparticles and gold nanoparticles. Talanta 2013, 116, 611-618. [CrossRef] [PubMed]

14. Wang, W.; Wu, S.; Ma, X.; Xia, Y.; Wang, Z. Novel methods for Fumonisins B1 detection based on AuNPs labeling and aptamer recognition. Shipin Yu Shengwu Jishu Xuebao 2013, 32, 501-508. (In Chinese)

15. Zhao, Y.; Luo, Y.; Li, T.; Song, Q. Au NPs driven electrochemiluminescence aptasensors for sensitive detection of fumonisin B1. RSC Adv. 2014, 4, 57709-57714. [CrossRef]

16. Li, C.; Mi, T.; Conti, G.O.; Yu, Q.; Wen, K.; Shen, J.; Ferrante, M.; Wang, Z. Development of a screening fluorescence polarization immunoassay for the simultaneous detection of fumonisins $\mathrm{B}_{1}$ and $\mathrm{B}_{2}$ in maize. J. Agric. Food Chem. 2015, 63, 4940-4946. [CrossRef] [PubMed]

17. Jodra, A.; Lopez, M.A.; Escarpa, A. Disposable and reliable electrochemical magnetoimmunosensor for Fumonisins simplified determination in maize-based foodstuffs. Biosens. Bioelectron. 2015, 64, 633-638. [CrossRef] [PubMed]

18. Masikini, M.; Mailu, S.; Tsegaye, A.; Njomo, N.; Molapo, K.; Ikpo, C.; Sunday, C.; Rassie, C.; Wilson, L.; Baker, P.; et al. A fumonisins immunosensor based on polyanilino-carbon nanotubes doped with palladium telluride quantum dots. Sensors (Basel) 2015, 15, 529-546. [CrossRef] [PubMed]

19. Chen, X.; Bai, X.; Li, H.; Zhang, B. Aptamer-based microcantilever array biosensor for detection of fumonisin B-1. RSC Adv. 2015, 5, 35448-35452. [CrossRef]

20. Chen, X.; Huang, Y.; Ma, X.; Jia, F.; Guo, X.; Wang, Z. Impedimetric aptamer-based determination of the mold toxin fumonisin B1. Microchim. Acta 2015, 182, 1709-1714. [CrossRef]

21. Ezquerra, A.; Vidal, J.C.; Bonel, L.; Castillo, J.R. A validated multi-channel electrochemical immunoassay for rapid fumonisin B1 determination in cereal samples. Anal. Methods 2015, 7, 3742-3749. [CrossRef]

22. Shi, Z.; Zheng, Y.; Zhang, H.; He, C.; Wu, W.; Zhang, H. DNA electrochemical aptasensor for detecting fumonisins B-1 based on graphene and thionine nanocomposite. Electroanalysis 2015, 27, 1097-1103. [CrossRef]

23. Yang, X.; Zhou, X.; Zhang, X.; Qing, Y.; Luo, M.; Liu, X.; Li, C.; Li, Y.; Xia, H.; Qiu, J. A highly sensitive electrochemical immunosensor for fumonisin B1 detection in corn using single-walled carbon nanotubes/chitosan. Electroanalysis 2015, 27, 2679-2687. [CrossRef]

24. Hsueh, C.; Liu, Y.; Freund, M.S. Indirect electrochemical detection of type-B trichothecene mycotoxins. Anal. Chem. 1999, 71, 4075-4080. [CrossRef] [PubMed]

25. Maragos, C.M.; Jolley, M.E.; Nasir, M.S. Fluorescence polarization as a tool for the determination of deoxynivalenol in wheat. Food Addit. Contam. 2002, 19, 400-407. [CrossRef] [PubMed]

26. Maragos, C.M.; Plattner, R.D. Rapid fluorescence polarization immunoassay for the mycotoxin deoxynivalenol in wheat. J. Agric. Food Chem. 2002, 50, 1827-1832. [CrossRef] [PubMed]

27. Schnerr, H.; Vogel, R.F.; Niessen, L. A biosensor-based immunoassay for rapid screening of deoxynivalenol contamination in wheat. Food Agric. Immunol. 2002, 14, 313-321. [CrossRef]

28. Tudos, A.J.; Lucas-van, D.B.E.; Stigter, E.C. Rapid surface plasmon resonance-based inhibition assay of deoxynivalenol. J. Agric. Food Chem. 2003, 51, 5843-5848. [CrossRef] [PubMed]

29. Ngundi, M.M.; Qadri, S.A.; Wallace, E.V.; Moore, M.H.; Lassman, M.E.; Shriver-Lake, L.C.; Ligler, F.S.; Taitt, C.R. Detection of deoxynivalenol in foods and indoor air using an array biosensor. Environ. Sci. Technol. 2006, 40, 2352-2356. [CrossRef] [PubMed]

30. Lippolis, V.; Pascale, M.; Visconti, A. Optimization of a fluorescence polarization immunoassay for rapid quantification of deoxynivalenol in durum wheat-based products. J. Food Prot. 2006, 69, 2712-2719. [PubMed]

31. Romanazzo, D.; Ricci, F.; Volpe, G.; Elliott, C.T.; Vesco, S.; Kroeger, K.; Moscone, D.; Stroka, J.; van Egmond, H.; Vehniainen, M.; et al. Development of a recombinant Fab-fragment based electrochemical immunosensor for deoxynivalenol detection in food samples. Biosens. Bioelectron. 2010, 25, 2615-2621. [CrossRef] [PubMed] 
32. Meneely, J.; Fodey, T.; Armstrong, L.; Sulyok, M.; Krska, R.; Elliott, C. Rapid surface plasmon resonance immunoassay for the determination of deoxynivalenol in wheat, wheat products, and maize-based baby food. J. Agric. Food Chem. 2010, 58, 8936-8941. [CrossRef] [PubMed]

33. Kadota, T.; Takezawa, Y.; Hirano, S.; Tajima, O.; Maragos, C.M.; Nakajima, T.; Tanaka, T.; Kamata, Y.; Sugita-Konishi, Y. Rapid detection of nivalenol and deoxynivalenol in wheat using surface plasmon resonance immunoassay. Anal. Chim. Acta 2010, 673, 173-178. [CrossRef] [PubMed]

34. Maragos, C.M. Detection of deoxynivalenol using biolayer interferometry. Mycotox. Res. 2011, 27, 157-165. [CrossRef] [PubMed]

35. Maragos, C.M. Signal amplification using colloidal gold in a biolayer interferometry-based immunosensor for the mycotoxin deoxynivalenol. Food Addit. Contam. Part A Chem. Anal. Control Expo. Risk Assess. 2012, 29, 1108-1117. [CrossRef] [PubMed]

36. Majer-Baranyi, K.; Székács, A.; Szendrő, I.; Kiss, A.; Adányi, N. Optical waveguide lightmode spectroscopy technique-based immunosensor development for deoxynivalenol determination in wheat samples. Eur. Food Res. Technol. 2011, 233, 1041-1047. [CrossRef]

37. Wei, Z.; Sun, X.; Li, Z.; Fang, Y.; Ren, G.; Huang, Y.; Liu, J. Highly sensitive deoxynivalenol immunosensor based on a glassy carbon electrode modified with a fullerene/ferrocene/ionic liquid composite. Microchim. Acta 2011, 172, 365-371.

38. Choi, S.; Chang, H.; Lee, N.; Chun, H.S. A surface plasmon resonance sensor for the detection of deoxynivalenol using a molecularly imprinted polymer. Sensors 2011, 11, 8654-8664. [CrossRef] [PubMed]

39. Kwon, I.; Lee, H.; Choi, J.; Shin, J.; Seo, S.; Choi, S.; Chun, H.S. Extended-gate metal oxide semiconductor field effect transistor-based biosensor for detection of deoxynivalenol. Jpn J. Appl. Phys. 2011, 50. [CrossRef]

40. Zhao, Y.; Wang, P.; Wang, F.; Zhou, H.; Li, W.; Yue, J.; Ha, Y. A novel biosensor regulated by the rotator of $\mathrm{F}(0) \mathrm{F}(1)$-ATPase to detect deoxynivalenol rapidly. Biochem. Biophys. Res. Commun. 2012, 423, 195-199. [CrossRef] [PubMed]

41. Valenzano, S.; Lippolis, V.; Pascale, M.; De Marco, A.; Maragos, C.M.; Suman, M.; Visconti, A. Determination of deoxynivalenol in wheat bran and whole-wheat flour by fluorescence polarization immunoassay. Food Anal. Methods 2014, 7, 806-813. [CrossRef]

42. Olcer, Z.; Esen, E.; Muhammad, T.; Ersoy, A.; Budak, S.; Uludag, Y. Fast and sensitive detection of mycotoxins in wheat using microfluidics based Real-time Electrochemical Profiling. Biosens. Bioelectron. 2014, 62, 163-169. [CrossRef] [PubMed]

43. Lv, X.; Li, Y.; Yan, T.; Pang, X.; Cao, W.; Du, B.; Wu, D.; Wei, Q. Electrochemiluminescence modified electrodes based on RuSi@Ru(bpy) ${ }_{3}{ }^{2+}$ loaded with gold functioned nanoporous $\mathrm{CO} / \mathrm{Co}_{3} \mathrm{O}_{4}$ for detection of mycotoxin deoxynivalenol. Biosens. Bioelectron. 2015, 70, 28-33. [CrossRef] [PubMed]

44. Sunday, C.E.; Masikini, M.; Wilson, L.; Rassie, C.; Waryo, T.; Baker, P.G.; Iwuoha, E.I. Application on gold nanoparticles-dotted 4-nitrophenylazo graphene in a label-free impedimetric deoxynivalenol immunosensor. Sensors 2015, 15, 3854-3871. [CrossRef] [PubMed]

45. Yoshinari, T.; Ohashi, H.; Abe, R.; Kaigome, R.; Ohkawa, H.; Sugita-Konishi, Y. Development of a rapid method for the quantitative determination of deoxynivalenol using Quenchbody. Anal. Chim. Acta 2015, 888, 126-130. [PubMed]

46. Nabok, A.V.; Tsargorodskaya, A.; Holloway, A.; Starodub, N.F.; Gojster, O. Registration of T-2 mycotoxin with total internal reflection ellipsometry and QCM impedance methods. Biosens. Bioelectron. 2007, 22, 885-890. [CrossRef] [PubMed]

47. Meneely, J.P.; Sulyok, M.; Baumgartner, S.; Krska, R.; Elliott, C.T. A rapid optical immunoassay for the screening of T-2 and HT-2 toxin in cereals and maize-based baby food. Talanta 2010, 81, 630-636. [CrossRef] [PubMed]

48. Lippolis, V.; Pascale, M.; Valenzano, S.; Pluchinotta, V.; Baumgartner, S.; Krska, R.; Visconti, A. A rapid fluorescence polarization immunoassay for the determination of T-2 and HT-2 toxins in wheat. Anal. Bioanal. Chem. 2011, 401, 2561-2571. [CrossRef] [PubMed]

49. Gupta, G.; Bhaskar, A.S.B.; Tripathi, B.K.; Pandey, P.; Boopathi, M.; Rao, P.V.L.; Singh, B.; Vijayaraghavan, R. Supersensitive detection of T-2 toxin by the in situ synthesized $\pi$-conjugated molecularly imprinted nanopatterns. An in situ investigation by surface plasmon resonance combined with electrochemistry. Biosens. Bioelectron. 2011, 26, 2534-2540. [CrossRef] [PubMed] 
50. Nabok, A.; Tsargorodskaya, A.; Mustafa, M.K.; Szekacs, I.; Starodub, N.F.; Szekacs, A. Detection of low molecular weight toxins using an optical phase method of ellipsometry. Sens. Actuators B 2011, 154, 232-237. [CrossRef]

51. Gao, X.; Cao, W.; Chen, M.; Xiong, H.; Zhang, X.; Wang, S. A high sensitivity electrochemical sensor based on $\mathrm{Fe}^{3+}$-ion molecularly imprinted film for the detection of T-2 toxin. Electroanalysis 2014, 26, 2739-2746. [CrossRef]

52. Toro, P.C.D.; Arévalo, F.J.; Fumero, M.V.; Zon, M.A.; Fernández, H. Very sensitive electrochemical sensor for moniliformin detection in maize samples. Sens. Actuators B 2016, 225, 384-390. [CrossRef]

53. Carter, R.M.; Blake, R.C.; Mayer, H.P.; Echevarria, A.A.; Nguyen, T.D.; Bostanian, L.A. A fluorescent biosensor for detection of zearalenone. Anal. Lett. 2000, 33, 405-412. [CrossRef]

54. Maragos, C.M.; Kim, E.K. Detection of zearalenone and related metabolites by fluorescence polarization immunoassay. J. Food Prot. 2004, 67, 1039-1043. [PubMed]

55. Andreu, Y.; Castillo, J.R.; de Marcos, S.; Galbán, J. Evaluation of a fluorometric-enzymatic method based on $3 \alpha$-hydroxysteroid dehydrogenase for the mycotoxin zearalenone determination in corn. Talanta 2004, 64, 196-201. [CrossRef] [PubMed]

56. Urraca, J.L.; Benito-Pena, E.; Perez-Conde, C.; Moreno-Bondi, M.C.; Pestka, J.J. Analysis of zearalenone in cereal and Swine feed samples using an automated flow-through immunosensor. J. Agric. Food Chem. 2005, 53, 3338-3344. [CrossRef] [PubMed]

57. Chang, H.J.; Choi, E.H.; Eremin, S.A.; Kim, H.J.; Chung, D.H.; Chun, H.S. Rapid fluorescence polarization immunoassay for the determination of zearalenone in maize. J. Kasetsart Vet. (Thailand) 2006, 16, 46.

58. Navarro-Villoslada, F.; Urraca, J.L.; Moreno-Bondi, M.C.; Orellana, G. Zearalenone sensing with molecularly imprinted polymers and tailored fluorescent probes. Sens. Actuators B 2007, 121, 67-73. [CrossRef]

59. Dall'Asta, C.; Faccini, A.; Galaverna, G.; Corradini, R.; Dossena, A.; Marchelli, R. Complexation of the mycotoxin zearalenone with beta-cyclodextrin: Study of the interaction and first promising applications. Mycotoxin Res. 2008, 24, 14-18. [CrossRef] [PubMed]

60. Chun, H.S.; Choi, E.H.; Chang, H.; Choi, S.; Eremin, S.A. A fluorescence polarization immunoassay for the detection of zearalenone in corn. Anal. Chim. Acta 2009, 639, 83-89. [CrossRef] [PubMed]

61. Hervás, M.; López, M.Á.; Escarpa, A. Electrochemical immunoassay using magnetic beads for the determination of zearalenone in baby food: An anticipated analytical tool for food safety. Anal. Chim. Acta 2009, 653, 167-172. [CrossRef] [PubMed]

62. Choi, S.; Chang, H.; Lee, N.; Kim, J.; Chun, H.S. Detection of mycoestrogen zearalenone by a molecularly imprinted polypyrrole-based surface plasmon resonance (SPR) sensor. J. Agric. Food Chem. 2009, 57, 1113-1118. [CrossRef] [PubMed]

63. Valimaa, A.L.; Kivisto, A.T.; Leskinen, P.I.; Karp, M.T. A novel biosensor for the detection of zearalenone family mycotoxins in milk. J. Microbiol. Methods 2010, 80, 44-48. [CrossRef] [PubMed]

64. Panini, N.V.; Bertolino, F.A.; Salinas, E.; Messina, G.A.; Raba, J. Zearalenone determination in corn silage samples using an immunosensor in a continuous-flow/stopped-flow systems. Biochem. Eng. J. 2010, 51, 7-13. [CrossRef]

65. Hervás, M.; López, M.Á.; Escarpa, A. Simplified calibration and analysis on screen-printed disposable platforms for electrochemical magnetic bead-based inmunosensing of zearalenone in baby food samples. Biosens. Bioelectron. 2010, 25, 1755-1760. [CrossRef] [PubMed]

66. Choi, E.H.; Kim, D.M.; Choi, S.; Eremin, S.A.; Chun, H.S. Optimisation and validation of a fluorescence polarisation immunoassay for rapid detection of zearalenone in corn. Int. J. Food Sci. Technol. 2011, 46, 2173-2181. [CrossRef]

67. Panini, N.V.; Salinas, E.; Messina, G.A.; Raba, J. Modified paramagnetic beads in a microfluidic system for the determination of zearalenone in feedstuffs samples. Food Chem. 2011, 125, 791-796. [CrossRef]

68. Bondarenko, A.P.; Eremin, S.A. Determination of zearalenone and ochratoxin A mycotoxins in grain by fluorescence polarization immunoassay. J. Anal. Chem. 2012, 67, 790-794. [CrossRef]

69. Beloglazova, N.V.; Shmelin, P.S.; Speranskaya, E.S.; Lucas, B.; Helmbrecht, C.; Knopp, D.; Niessner, R.; de Saeger, S.; Goryacheva, I.Y. Quantum dot loaded liposomes as fluorescent labels for immunoassay. Anal. Chem. 2013, 85, 7197-7204. [CrossRef] [PubMed] 
70. Chen, X.; Huang, Y.; Duan, N.; Wu, S.; Ma, X.; Xia, Y.; Zhu, C.; Jiang, Y.; Wang, Z. Selection and identification of ssDNA aptamers recognizing zearalenone. Anal. Bioanal. Chem. 2013, 405, 6573-6581. [CrossRef] [PubMed]

71. Feng, R.; Zhang, Y.; Ma, H.; Wu, D.; Fan, H.; Wang, H.; Li, H.; Du, B.; Wei, Q. Ultrasensitive non-enzymatic and non-mediator electrochemical biosensor using nitrogen-doped graphene sheets for signal amplification and nanoporous alloy as carrier. Electrochim. Acta 2013, 97, 105-111. [CrossRef]

72. Liu, L.; Chao, Y.; Cao, W.; Wang, Y.; Luo, C.; Pang, X.; Fan, D.; Wei, Q. A label-free amperometric immunosensor for detection of zearalenone based on trimetallic Au-core/AgPt-shell nanorattles and mesoporous carbon. Anal. Chim. Acta 2014, 847, 29-36. [CrossRef] [PubMed]

73. Fang, G.; Fan, C.; Liu, H.; Pan, M.; Zhu, H.; Wang, S. A novel molecularly imprinted polymer on CdSe/ZnS quantum dots for highly selective optosensing of mycotoxin zearalenone in cereal samples. RSC Adv. 2014, 4, 2764-2771. [CrossRef]

74. Afzali, D.; Padash, M.; Mostafavi, A. Determination of trace amounts of zearalenone in beverage samples with an electrochemical sensor. Mycotoxin Res. 2015, 31, 203-208. [CrossRef] [PubMed]

75. Wang, Y.K.; Zou, Q.; Sun, J.H.; Wang, H.A.; Sun, X.; Chen, Z.F.; Yan, Y.X. Screening of single-stranded DNA (ssDNA) aptamers against a zearalenone monoclonal antibody and development of a ssDNA-based enzyme-linked oligonucleotide assay for determination of zearalenone in corn. J. Agric. Food Chem. 2015, 63, 136-141. [CrossRef] [PubMed]

76. Regiart, M.; Seia, M.A.; Messina, G.A.; Bertolino, F.A.; Raba, J. Electrochemical immunosensing using a nanostructured functional platform for determination of alpha-zearalanol. Microchim. Acta 2015, 182, 531-538. [CrossRef]

77. Wang, X.; He, Q.; Xu, Y.; Liu, X.; Shu, M.; Tu, Z.; Li, Y.; Wang, W.; Cao, D. Anti-idiotypic VHH phage display-mediated immuno-PCR for ultrasensitive determination of mycotoxin zearalenone in cereals. Talanta 2016, 147, 410-415. [CrossRef] [PubMed]

78. Sadrabadi, N.R.; Ensafi, A.A.; Heydari-Bafrooei, E.; Fazilati, M. Screening of food samples for zearalenone toxin using an electrochemical bioassay based on DNA-zearalenone interaction. Food Anal. Methods 2016. [CrossRef]

79. Van der Gaag, B.; Spath, S.; Dietrich, H.; Stigter, E.; Boonzaaijer, G.; van Osenbruggen, T.; Koopal, K. Biosensors and multiple mycotoxin analysis. Food Control 2003, 14, 251-254. [CrossRef]

80. Ligler, F.S.; Taitt, C.R.; Shriver-Lake, L.C.; Sapsford, K.E.; Shubin, Y.; Golden, J.P. Array biosensor for detection of toxins. Anal. Bioanal. Chem. 2003, 377, 469-477. [CrossRef] [PubMed]

81. Ngundi, M.M.; Shriver-Lake, L.C.; Moore, M.H.; Ligler, F.S.; Taitt, C.R. Multiplexed detection of mycotoxins in foods with a regenerable array. J. Food Prot. 2006, 69, 3047-3051. [PubMed]

82. Ligler, F.S.; Sapsford, K.E.; Ngundi, M.M.; Moore, M.H.; Lassman, M.E.; Shriver-Lake, L.C.; Taitt, C.R. Rapid detection of foodborne contaminants using an Array Biosensor. Sens. Actuators B 2006, 113, 599-607.

83. Mak, A.C.; Osterfeld, S.J.; Yu, H.; Wang, S.X.; Davis, R.W.; Jejelowo, O.A.; Pourmand, N. Sensitive giant magnetoresistive-based immunoassay for multiplex mycotoxin detection. Biosens. Bioelectron. 2010, 25, 1635-1639. [CrossRef] [PubMed]

84. Dorokhin, D.; Haasnoot, W.; Franssen, M.C.; Zuilhof, H.; Nielen, M.W. Imaging surface plasmon resonance for multiplex microassay sensing of mycotoxins. Anal. Bioanal. Chem. 2011, 400, 3005-3011. [CrossRef] [PubMed]

85. Wu, S.; Duan, N.; Ma, X.; Xia, Y.; Wang, H.; Wang, Z.; Zhang, Q. Multiplexed fluorescence resonance energy transfer aptasensor between upconversion nanoparticles and graphene oxide for the simultaneous determination of mycotoxins. Anal. Chem. 2012, 84, 6263-6270. [CrossRef] [PubMed]

86. Beloglazova, N.V.; Speranskaya, E.S.; Wu, A.; Wang, Z.; Sanders, M.; Goftman, V.V.; Zhang, D.; Goryacheva, I.Y.; de Saeger, S. Novel multiplex fluorescent immunoassays based on quantum dot nanolabels for mycotoxins determination. Biosens. Bioelectron. 2014, 62, 59-65. [CrossRef] [PubMed]

87. Spinella, K.; Mosiello, L.; Palleschi, G.; Vitali, F. Development of a QCM (Quartz Crystal Microbalance) biosensor to detection of mycotoxins. In Sensors and Microsystems, Proceedings of the 17th National Conference, Brescia, Italy, 5-7 February 2013; di Natale, C., Ed.; Springer International Publishing: Cham, Switzerland, 2014; pp. 195-198. 
88. Sun, Y.; Xu, J.; Li, W.; Cao, B.; Wang, D.; Yang, Y.; QingXia, L.; Li, J.; Zheng, T. Simultaneous detection of ochratoxin A and fumonisin B1 in cereal samples using an aptamer-photonic crystal encoded suspension array. Anal. Chem. 2014, 86, 11797-11802.

89. Zangheri, M.; Di Nardo, F.; Anfossi, L.; Giovannoli, C.; Baggiani, C.; Roda, A.; Mirasoli, M. A multiplex chemiluminescent biosensor for type B-fumonisins and aflatoxin B1 quantitative detection in maize flour. Analyst (Cambridge, UK) 2015, 140, 358-365. [CrossRef] [PubMed]

90. Kong, D.; Liu, L.; Song, S.; Suryoprabowo, S.; Li, A.; Kuang, H.; Wang, L.; Xu, C. A gold nanoparticle-based semi-quantitative and quantitative ultrasensitive paper sensor for the detection of twenty mycotoxins. Nanoscale 2016, 8, 5245-5253. [CrossRef] [PubMed]

91. Joshi, S.; Segarra-Fas, A.; Peters, J.; Zuilhof, H.; van Beek, T.A.; Nielen, M.W. Multiplex surface plasmon resonance biosensing and its transferability towards imaging nanoplasmonics for detection of mycotoxins in barley. Analyst 2016, 141, 1307-1318. [CrossRef] [PubMed]

92. Shankaran, D.; Gobi, K.; Miura, N. Recent advancements in surface plasmon resonance immunosensors for detection of small molecules of biomedical, food and environmental interest. Sens. Actuators B 2007, 121, 158-177. [CrossRef]

93. Hodnik, V.; Anderluh, G. Toxin detection by surface plasmon resonance. Sensors (Basel) 2009, 9, $1339-1354$. [CrossRef] [PubMed]

94. Thompson, V.S.; Maragos, C.M. Measurement of fumonsins in corn with a fiber-optic fluoroimmunosensor. In Proceedings of the SPIE 2980: Advances in Fluorescence Sensing Technology III, San Jose, CA, USA, 7 May 1997; pp. 532-538.

95. Hervas, M.; Angel Lopez, M.; Escarpa, A. Electrochemical microfluidic chips coupled to magnetic bead-based ELISA to control allowable levels of zearalenone in baby foods using simplified calibration. Analyst 2009, 134, 2405-2411. [CrossRef] [PubMed]

96. Hervas, M.; Lopez, M.A.; Escarpa, A. Integrated electrokinetic magnetic bead-based electrochemical immunoassay on microfluidic chips for reliable control of permitted levels of zearalenone in infant foods. Analyst 2011, 136, 2131-2138. [CrossRef] [PubMed]

97. McKeague, M.; Bradley, C.R.; De Girolamo, A.; Visconti, A.; Miller, J.D.; Derosa, M.C. Screening and initial binding assessment of fumonisin B1 aptamers. Int. J. Mol. Sci. 2010, 11, 4864-4881. [CrossRef] [PubMed]

(C) 2016 by the authors; licensee MDPI, Basel, Switzerland. This article is an open access article distributed under the terms and conditions of the Creative Commons Attribution (CC-BY) license (http://creativecommons.org/licenses/by/4.0/). 